\title{
MODIFIKASI MEAs DENGAN MENGGUNAKAN DIDACTICAL DESIGN RESEARCH UNTUK MENINGKATKAN KEMAMPUAN BERPIKIR STATISTIS MAHASISWA
}

\author{
Bambang Avip Priatna Martadiputra \\ FPMIPA Universitas Pendidikan Indonesia \\ email: bambangavip@yahoo.com
}

\begin{abstract}
Abstrak: Artikel ini berisi hasil penelitian tentang bagaimana cara memodifikasi pembelajaran ModelEliciting Activities (MEAs) dengan menggunakan Didactical Design Research (DDR). Metode yang digunakan adalah Research \& Development melalui tahap-tahap: persiapan untuk mengetahui efektivitas bahan ajar, pembelajaran MEAs yang dimodifikasi, tingkat validitas, reliabilitas, daya pembeda, dan indeks kesukaran instrumen tes; pelaksanaan penelitian berupa uji coba pembelajaran MEAs yang dimodifikasi terhadap seluruh mahasiswa S1 pendidikan matematika yang mengikuti mata kuliah Statistika Dasar pada semester genap TA. 2011/2012 di sebuah PTN di Kota Bandung dengan metode kuasi-eksperimen menggunakan Split-Plot Nested Design. Hasil penelitian menunjukkan bahwa peningkatan kemampuan berpikir statistis mahasiswa reguler dan mahasiswa mengulang yang memperoleh pembelajaran MEAs yang dimodifikasi lebih tinggi secara signifikan dari mahasiswa yang memperoleh pembelajaran konvensional.
\end{abstract}

Kata Kunci: Model-Eliciting Activities (MEAs) yang dimodifikasi, didactical disain research

\section{MODIFICATION OF THE MEAS USING THE DIDACTICAL DESIGN RESEARCH TO IMPROVE THE STUDENTS' STATISTICAL REASONING ABILITY}

\begin{abstract}
This paper contains the findings of the study on how to modify the Model-ElicitngActivities (MEAs) teaching using the Didactical Design Research (DDR). The method used was the research and development through the following steps: preparation to find out the effectiveness of the teaching materials, modified MEAs teaching, the validity level, reliability, the discrimination level, and the test instrument difficulty index; the research implementation in the form of piloting the modified MEAs teaching to the undergraduate students of the Mathematics education program joining the Elementary Statistics course in the second semester of the 2011/2012 year in a state university in Bandung using the quasi-experiment with the Split-Plot Nested Design. The findings showed that the improvement of the statistical reasoning of the regular students and the repeaters obtaining the modified MEAs teaching was significantly higher than that of those obtaining the conventional teaching.
\end{abstract}

Keywords: Modified Model-Eliciting Activities (MEAs), Didactical Design Research (DDR)

\section{PENDAHULUAN}

Merujuk pada pendapat Jones, et al. (2000), delMas (2002), Chance (2002), serta Ben-Zvi \& Friedlander (2010), kemampuan berpikir statistis diartikan sebagai kemampuan untuk mengerti dan memahami bagaimana cara mendeskripsikan data, mengorganisasikan data, merepresentasikan data, menganalisis dan menginterpretasikan data, serta kemampuan untuk mengaplikasikan pemahaman statistis pada masalah nyata dengan cara memberikan kritik, evaluasi, dan membuat generalisasi. Selanjutnya berdasarkan tahap berpikir kognitif model Structure of the Observed
Learning Outcome (SOLO), Jones, et al. (2000) membagi tingkatan kemampuan berpikir statistis dalam empat level, yaitu Idiosyncratic, Transitional, Quantitative, dan Analytical.

Tingkat terendah dari kemampuan berpikir statistis disebut level Idiosyncratic yang ditandai dengan munculnya kemampuan berpikir prestruktural tetapi terganggu atau dikacaukan oleh aspek-aspek yang tidak relevan. Tingkatan selanjutnya disebut level Transitional yaitu seseorang mencoba untuk menyajikan gagasannya melalui berpikir kuantatif tetapi secara umum perhatiannya tertuju 
hanya pada satu aspek dari data, kadangkadang mundur ke level Idiosyncratic. Tingkatan kemampuan berpikir statistis yang lebih tinggi daripada level Idiosyncratic dan level Transitional disebut level Quantitative, yaitu kemampuan berpikir kuantitatif yang tertuju pada lebih dari satu aspek tugas eksplorasi data. Tingkatan tertinggi dari kemampuan berpikir statistis disebut level Analytical, yaitu kemampuan berpikir analitis dan kuantitatif tentang data serta mampu menjelaskan berbagai perspektif berdasarkan data yang diperoleh.

Hasil penelitian Martadiputra dan Tapilouw (2011) mengindikasikan bahwa kemampuan berpikir statistis mahasiswa program studi matematika maupun program studi pendidikan matematika yang belum maupun yang sudah lulus S1 di sebuah PTN di Bandung masih belum optimal karena baru mencapai level Transitional atau Quantitative, dan hanya sebagian kecil (kurang dari 10\%) yang memasuki level Analytical. Khusus untuk kemampuan berpikir statistis berkaitan dengan menganalisis dan menginterpretasikan data, ternyata tidak ada satu mahasiswapun yang sampai pada level Analytical.

Belum optimalnya kemampuan berpikir stasistis mahasiswa tersebut diduga disebabkan oleh kurang tepatnya model atau pendekatan pembelajaran yang digunakan oleh dosen dalam perkuliahan Statistika Dasar. Oleh karena itu, penulis berupaya untuk memodifikasi pembelajaran Model-Eliciting Activities (MEAs) dengan menggunakan Didactical Design Research (DDR) dengan harapan akan ditemukan sebuah pembelajaran statistika yang dapat mengoptimalkan peningkatan kemampuan berpikir statistis mahasiswa.

Lesh \& Doerr (2003) mengemukakan bahwa ada enam prinsip dari pembelajaran MEAs, yaitu prinsip konstruksi, prinsip realitas, prinsip self-assessment, prinsip dokumentasi, prinsip reusability dan berbagi-kemampuan, dan prinsip prototipe yang efektif. Selanjutnya hasil penelitian Lesh \& Doerr (2003), DiefesDux, H. A., Imbrie, P. K., \& Moore, T. J. (2005, 2007); dan Zawojewski, Bowman \& Di-
efes-Dux (2008), serta Garfield, delMas dan Zieffler (2010) menunjukkan bahwa dengan menggunakan pembelajaran MEAs akan membantu siswa pada pemahaman konseptual, kemampuan pemecahan masalah, retensi, dan transfer pengetahuan yang lebih baik.

Tujuan dari penelitian ini adalah sebagai berikut. (1) Memodifikasi pembelajaran MEAs yang telah dikembangkan oleh Lesh \& Doerr (2003), Diefes, H.A., Moore, T., Zawojewski, J., Imbrie, P.K., and Follman, D. (2003); Diefes-Dux, H. A., Imbrie, P. K., \& Moore, T. J. (2005, 2006, 2007); dan Zawojewski, Bowman \& Diefes-Dux (2008), serta Garfield, delMas dan Zieffler (2010) dengan menggunakan Disain Didactiacal Reasearch (DDR) yang akan digunakan pada perkuliahan Statistika Dasar dan dapat lebih mengoptimalkan peningkatan kemampuan berpikir statistis mahasiswa. (2) Menganalisis apakah peningkatan kemampuan berpikir statistis mahasiswa yang memperoleh pembelajaran MEAs yang dimodifikasi lebih tinggi daripada mahasiswa yang memperoleh pembelajaran konvensional.

\section{METODE}

Dalam penelitian ini digunakan Research \& Depelopment Method (R\&D) selama satu tahun. Secara garis besar penelitian dibagi menjadi dua tahap, yaitu sebagai berikut. (1) Tahap pertama disebut tahap persiapan, yaitu berupa penelitian pengembangan (development research) bahan ajar dan pembelajaran MEAs yang dimodifikasi, serta pembuatan instrumen penelitian berupa: Tes Kemampuan Statistis Awal (TKAS) dan Tes Kemampuan Berpikir Statistis (TKBS). (2) Tahap kedua berupa kegiatan pelaksanaan penelitian. Pada penelitian tahap pertama digunakan disain penelitian satu kelompok tanpa kontrol: X O untuk mengetahui efektivitas dari bahan ajar dan pembelajaran MEAs yang dimodifikasi, serta tingkat validitas, reliabilitas, daya pembeda, dan indeks kesukaran butir soal TKAS dan TKBS yang dilakukan terhadap satu kelas mahasiswa S1 pendidikan matematika di sebuah PTN di kota Bandung selama satu semester. 
Pada tahap kedua, penelitian dilakukan lewat uji coba pembelajaran MEAs yang dimodifikasi terhadap seluruh mahasiswa S1 pendidikan matematika yang mengikuti mata kuliah Statistika Dasar untuk materi Statistika Deskriptif di sebuah PTN di Kota Bandung yang terdiri dari tiga kelas, yaitu: kelas kontrol, kelas eksperimen 1, dan kelas eksperimen 2 dengan menggunakan metode kuasi-eksperimen. Dalam penelitian ini digunakan desain kelompok kontrol dengan pretes dan postes berbentuk: $\mathrm{O} \mathrm{X}$ O; O X O; dan O O. Rancangan percobaannya menggunakan Split-Plot Nested Design dengan model linear (Gaspersz, V, 2006), yaitu:

$$
\begin{gathered}
\mathrm{Y}_{\mathrm{ijkl}}=\mu+\kappa_{\mathrm{l}}+\alpha_{\mathrm{i}}+\delta_{\mathrm{il}}+\beta_{\mathrm{j}}+(\alpha \beta)_{\mathrm{ij}}+\lambda_{\mathrm{ijl}}+\gamma_{\mathrm{k}}+ \\
(\alpha \gamma)_{\mathrm{ik}}+(\beta \gamma)_{\mathrm{jk}}+(\alpha \beta \gamma)_{\mathrm{ijk}}+\varepsilon_{\mathrm{ijkl}}
\end{gathered}
$$

untuk: $\mathrm{i}=1,2,3 ; \mathrm{j}=1,2 ; \mathrm{k}=1,2 ;$ dan $1=$ $1,2,3, \ldots, \mathrm{n}_{\mathrm{i}}$

Alasannya penggunaan Split-Plot Nested Design karena penelitian ini berkaitan dengan percobaan yang berhadapan dengan masalah ukuran petak (plot), yaitu faktor model pembelajaran dipandang oleh peneliti berpengaruh lebih besar terhadap peningkatan kemampuan berpikir statistis mahasiswa daripada faktor pengelompokkan mahasiswa berdasarkan kemampuan statistis awal yang dimilikinya (Gasperst, V, 2006). Faktor pengelompokkan kemampuan statistika awal (rendah, sedang, tinggi) ditempatkan sebagai petak utama (mainplot), faktor pembelajaran (konvensional dan MEAs yang dimodifikasi) ditempatkan sebagai anak petak (subplot), sedangkan faktor mahasiswa (reguler dan mengulang) ditempatkan sebagai anak-anak petak. Kelas eksperimen terdiri dua kelas, yaitu kelas mahasiswa reguler (41 orang) dan kelas mahasiswa mengulang (12 orang) yang memperoleh pembelajaran MEAs yang dimodifikasi. Sedangkan kelas kontrolnya adalah kelas mahasiswa reguler (39 orang) yang memperoleh pembelajaran konvensional.

Sebelum semua kelas diberi perlakuan, dilakukan pengukuran kemampuan berpikir statistis awal dengan menggunakan TKAS. Berdasarkan hasil TKAS, mahasiswa pada setiap kelas dikelompokkan menjadi menjadi tiga katagori, yaitu: rendah, sedang, dan tinggi. Kemampuan awal dan kemampuan akhir berpikir statistis mahasiswa diukur dengan menggunakan TKBS sedemikian sehingga akan diketahui peningkatan kemampuan berpikir statistis mahasiswa. Untuk menjawab permasalahan penelitian, dilakukan pengolahan dan analisis data dengan menggunakan mix-methods, yaitu gabuangan antara analisis kuantitatif dan analisis kualitatif disesuaikan dengan data yang ada.

\section{HASIL DAN PEMBAHASAN \\ Pembelajaran MEAs yang Dimodifikasi}

Pembelajaran Model-Eliciting Activities (MEAs) yang dimodifikasi adalah pembelajaran MEAs yang yang diperoleh dengan cara sebagai berikut.

\section{Memodifikasi Bahan Ajar Pembelajaran MEAs Sebelumnya}

Sebelum digunakan pada pembelajaran yang sesungguhnya, dosen melakukan pengembangan bahan ajar pembelajaran MEAs yang dimodifikasi dengan menggunakan DDR melalui tiga tahap, yaitu sebagai berikut. (1) Analisis situasi didaktis yang dilakukan dosen sebelum uji coba bahan ajar, berisi prediksi dan antisipasi terhadap setiap kemungkinan respons mahasiswa yang muncul atas situasi didaktis dan situasi pedagogis yang dimunculkan. (2) Analisis metapedadidaktik yang dilakukan dosen pada saat uji coba bahan ajar, berisi identifikasi dan analisis tentang hambatan pembelajaran (learning obstacles) yang muncul pada saat pembelajaran berlangsung. (3) Analisis retrosfektif yang dilakukan setelah uji coba bahan ajar, berisi refleksi kesesuaian antara analisis situasi didaktis dengan analisis metapedadidaktik yang berisi tindakan didaktis dan pedagogis lanjutan. Jadi pada pembelajaran MEAs yang dimodifikasi bahan ajarnya telah diujicobakan dan disempurnakan sehingga hambatan pembelajaran yang mungkin muncul sudah terantisipasi oleh dosen.

Hasil penelitian mengenai pelaksanaan, tujuan, dan hasil dari analisis situasi didaktis, analisis metapedadidaktik, dan analisis retrosfektif bahan ajar pembelajaran MEAs yang dimodifikasiditunjukkan pada Tabel 1. 
Pengembangan bahan ajar pembelajaran MEAs yang dimodifikasi, tetap masih mempertahankan enam prinsip dari pembelajaran MEAs, yaitu prinsip konstruksi, prinsip realitas, prinsip self-assessment, prinsip dokumentasi, prinsip reusability, dan prinsip prototipe yang efektif. Akan tetapi, pada pembelajaran MEAs yang dimodifikasi bahan ajarnya telah diujicobakan dan disempurnakan dengan menggunakan DDR sehingga dapat lebih mengoptimalkan peningkatan kemampuan berpikir berpikir statistis mahasiswa dibandingkan dengan pembelajaran MEAs sebelumnya dan pembelajaran konvensional.
Alasan teoretis mengapa penggunaan Didactical Design Research (DDR) akan menghasilkan pembelajaran MEAs yang dapat mengoptimalkan kemampuan berpikir statistis mahasiswa seperti yang terlihat pada Tabel 1 .

- Analisis situasi didaktis yang dilakukan oleh dosen sebelum pembelajaran memungkinkan terciptanya suatu situasi didaktis yang ideal bagi mahasiswa (Suryadi, 2010). Hal ini terjadi karena analisis situasi didaktis berisi pemikiran dosen tentang prediksi dan antisipasi terhadap respons mahasiswa yang akan dimunculkan pada situasi didaktis yang akan dimunculkan pada saat pembelajaran dengan

Tabel 1. Pelaksanaan, Tujuan, dan Hasil Analisis Situasi Didaktis, Analisis Metapedadidaktik, dan Analisis Retrosfektif Bahan Ajar Pembelajaran MEAs yang Dimodifikasi

\begin{tabular}{|c|c|c|c|c|}
\hline No. & Analisis & Pelaksanaan & Tujuan & Hasil \\
\hline 1. & $\begin{array}{l}\text { Situasi } \\
\text { Didaktis }\end{array}$ & $\begin{array}{l}\text { Sebelum } \\
\text { pembelajaran }\end{array}$ & $\begin{array}{l}\text { Membuat bahan ajar (rencana } \\
\text { pembelajaran) sesuai dengan } \\
\text { keenam prinsip pembelajaran MEAs } \\
\text { yang dapat memprediksi dan } \\
\text { mengantisipasi setiap respons } \\
\text { mahasiswa yang muncul dari situasi } \\
\text { didaktis dan pedagogis yang akan } \\
\text { dimunculkan pada saat pembelajaran }\end{array}$ & $\begin{array}{l}\text { Bahan ajar yang sesuai } \\
\text { dengan kapasitas dan } \\
\text { kebutuhan mahasiswa }\end{array}$ \\
\hline 2. & $\begin{array}{l}\text { Metapeda- } \\
\text { didaktik }\end{array}$ & $\begin{array}{l}\text { Pada saat } \\
\text { pembelajaran } \\
\text { berlangsung }\end{array}$ & $\begin{array}{l}\text { Memperoleh tacit didactical and } \\
\text { pedagogical knowledge berupa } \\
\text { hambatan-hambatan pembelajaran } \\
\text { (learning obstacle) sebagai bahan } \\
\text { refleksi pasca pembelajaran }\end{array}$ & $\begin{array}{l}\text { Akan diketahui sifat dan } \\
\text { jenis hambatan belajar } \\
\text { (learning obstacles) yang } \\
\text { menyebabkan langkah- } \\
\text { langkah pembelajaran } \\
\text { MEAs yang dimodifikasi } \\
\text { tidak berjalan lancar dan } \\
\text { hasil belajar mahasiswa } \\
\text { belum optimal }\end{array}$ \\
\hline 3. & Retros-fektif & $\begin{array}{l}\text { Setelah } \\
\text { Pembelajaran }\end{array}$ & $\begin{array}{l}\text { Mengidentifikasi, menganalisis, serta } \\
\text { mengaitkan tacit didaktical and } \\
\text { pedagogical sebelum pembelajaran } \\
\text { berupa antisipasi didaktis dan } \\
\text { pedagogis dengan tacit knowledge } \\
\text { yang diperoleh pada saat } \\
\text { pembelajaran. }\end{array}$ & $\begin{array}{l}\text { Revisi bahan ajar (rencana } \\
\text { pembelajaran) awal } \\
\text { sehingga diperoleh bahan } \\
\text { ajar yang ideal, yaitu bahan } \\
\text { ajar yang: } \\
\text { (1) sesuai dengan kapasitas } \\
\text { dan kebutuhan } \\
\text { mahasiswa; } \\
\text { (2) tahapan pembelajar-an } \\
\text { berjalan lancar sehingga } \\
\text { hasil belajar menjadi } \\
\text { optimal. }\end{array}$ \\
\hline
\end{tabular}


memperhatikan keenam prinsip dari pembelajaran MEAs, yaitu prinsip: (1) konstruksi; (2) realitas; (3) self-assessment; (4) dokumentasi; (5) reusability dan berbagi-kemampuan; dan (6) prototipe yang efektif. Antisipasi tersebut tidak hanya menyangkut hubungan mahasiswa-materi, akan tetapi juga hubungan dosen-mahasiswa secara individu, kelompok, atau kelas.

- Analisis metapedadidaktik adalah kemampuan dosen terkait dengan peristiwa pembelajaran untuk: (1) memandang komponenkomponen segitiga didaktis yang dimodifikasi yaitu: ADP, HD, dan HP sebagai suatu kesatuan yang utuh; (2) mengembangkan tindakan sehingga tercipta situasi didaktis dan pedagogis yang sesuai kebutuhan mahasiswa; (3) mengidentifikasi serta menganalisis respons mahasiswa sebagai akibat tindakan didaktis maupun pedagogis yang dilakukan; dan (4) melakukan tindakan didaktis dan pedagogis lanjutan berdasarkan hasil analisis respons mahasiswa menuju pencapaian target pembelajaran. Implikasi dari analisis metapedadidaktik adalah tahapan pembelajaran akan berjalan lancar dan hasil belajar mahasiswa akan optimal (Suryadi, 2010).

- Analisis retrosfektif adalah kegiatan analisis yang dilakukan oleh dosen pascapembelajaran berupa analisis yang mengaitkan hasil analisis situasi didaktis berupa antisipasi didaktis dan pedagogis yang dilakukan sebelum pembelajaran dengan hasil analisis metapedadidaktik berupa tacit knowledge yang diperoleh pada peristiwa pembelajaran. Hasilnya berupa refleksi pasca pembelajaran. Implikasi dari analisis retrosfektif adalah akan diperoleh suatu strategi yang sangat baik untuk melakukan pengembangan diri dosen sehingga kualitas pembelajaran dari waktu ke waktu senantiasa dapat ditingkatkan (Suryadi, 2010)

Jadi, dari hasil pengembangan bahan ajar dengan menggunakan DDR, akan diperoleh beberapa keunggulan dari pembelajaran MEAs yang dimodifikasi dibandingkan dengan pem- belajaran MEAs sebelumya dan pembelajaran konvensional, yaitu sebaagi berikut. (1) Hasil analisis situasi didaktis akan memungkinkan terciptanya suatu situasi didaktis yang ideal bagi mahasiswa. (2) Hasil analisis metapedadidaktis, tahapan pembelajaran akan berjalan lancar dan hasil belajar mahasiswa akan optimal. (3) Analisis retrosfektif akan diperoleh suatu strategi yang sangat baik untuk melakukan pengembangan diri dosen sehingga kualitas pembelajaran dari waktu ke waktu senantiasa dapat ditingkatkan.

\section{Perbandingan Kemampuan Berpikir Statis- tis Mahasiswa Reguler dan Mengulang yang Memperoleh Pembelajaran MEAs yang Di- modifikasi dengan Mahasiswa Reguler yang Memperoleh Pembelajaran Konvensional}

Hasil analisis statistik deskriptif tentang kemampuan berpikir statistis mahasiswa reguler dan mengulang yang memperoleh pembelajaran MEAs yang dimodifikasi dengan mahasiswa regular yang memperoleh pembelajaran konvensional disajikan pada Tabel 2.

Pada Tabel 2, terlihat hal-hal sebagai berikut.

- Sebelum memperoleh pembelajaran, ratarata kemampuan berpikir statistis (KBS_Awal) mahasiswa mengulang relatif lebih tinggi daripada mahasiswa regular. Hal ini adalah wajar dikarenakan mahasiswa mengulang pernah mengikuti perkuliahan statistika dasar sebelumnya akan tetapi memperoleh nilai E atau D.

- Setelah memperoleh pembelajaran, rata-rata kemampuan berpikir statistis (KBS_Akhir) mahasiswa regular maupun mahasiswa mengulang yang memperoleh pembelajaran MEAs yang dimodifikasi relatif lebih tinggi daripada mahasiswa regular yang memperoleh pembelajaran konvensional. Ini mengindikasikan bahwa kemampuan berpikir statistis mahasiswa yang memperoleh pembelajaran MEAs yang dimodifikasi relatif lebih tinggi daripada mahasiswa yang memperoleh pembelajaran regular. 
Tabel 2. Tabel Winner Kemampuan Berpikir Statistis Mahasiswa

\begin{tabular}{lccrrrrr}
\hline & \multicolumn{5}{c}{ KEMAMPUAN BERPIKIR STATISTIS (KBS) } \\
\hline \multicolumn{1}{c}{ Kelas } & $\mathrm{n}$ & \multicolumn{2}{c}{ KBS_Awal } & \multicolumn{2}{c}{ KBS_Akhir } & \multicolumn{2}{c}{ Gain_KBS } \\
\hline Kontrol & 41 & 28,44 & $3 t d$. Dev & Mean & Std. Dev & Mean & Std. Dev \\
Eksperimen 1 & 39 & 27,98 & 4,33 & 76,76 & 13,88 & 0,6828 & 0,1793 \\
Eksperimen 2 & 12 & 30,83 & 3,79 & 80,83 & 10,26 & 0,7208 & 0,1546 \\
Total & 92 & 28,54 & 4,12 & 70,17 & 14,86 & 0,5863 & 0,2003 \\
\hline
\end{tabular}

Tabel 3. Hasil Analisis Statistik Inferensial (Taraf Signifikansi $\alpha=0,05$ )

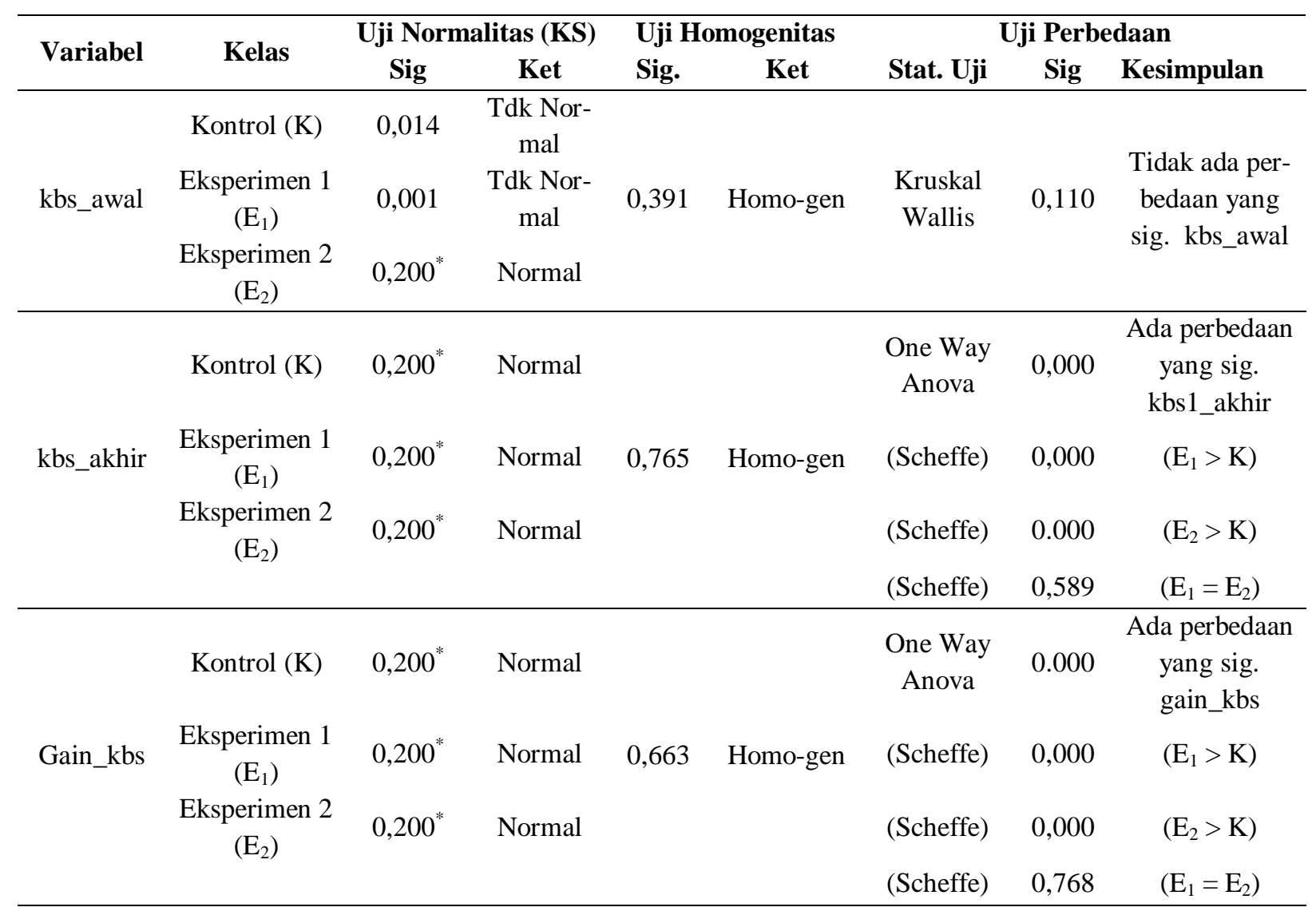

Tabel 4. Pengaruh Interaksi antara Faktor Pembelajaran dan Faktor Kemampuan Statistika Awal terhadap Peningkatan Kemampuan Berpikir Statistis Mahasiswa

\begin{tabular}{cllll}
\hline No. & \multicolumn{1}{c}{ Pengujian } & Statistik Uji & Nilai Sig & \multicolumn{1}{c}{ Kesimpulan } \\
\hline 1. & $\begin{array}{l}\text { Pengaruh interaksi antara model } \\
\text { pembelajaran dan kemampuan statistika } \\
\text { awal terhadap peningkatan kemampuan } \\
\text { berpikir statistis mahasiswa }\end{array}$ & ANOVA dua & 0,867 & Tidak ada pengaruh \\
& & & $\begin{array}{l}\text { yang signifikan } \\
\text { Pengaruhnya hanya } \\
\text { sebesar 1,5\% }\end{array}$ \\
\hline
\end{tabular}

- Setelah memperoleh pembelajaran MEAs yang dimodifikasi, rata-rata kemampuan berpikir statistis (KBS_Akhir) mahasiswa mengulang relatif lebih tinggi daripada mahasiswa regular. 
- Rata-rata peningkatan kemampuan berpikir statistis (Gain_KBS) mahasiswa regular dan mengulang yang memperoleh pembelajaran MEAs yang dimodifikasi relatif lebih tinggi daripada mahasiswa regular yang memperoleh pembelajaran konvensional. Ini mengindikasikan bahwa pembelajaran MEAs yang dimodifikasi dapat lebih mengoptimalkan peningkatan kemampuan berpikir statistis mahasiswa daripada pembelajaran konvensional.

Hasil analisis statistik inferensial untuk uji perbedaan kemampuan berpikir statistis mahasiswa reguler dan mengulang yang memperoleh pembelajaran MEAs yang dimodifikasi dengan mahasiswa regular yang memperoleh pembelajaran konvensional disajikan dalam Tabel 3.

Tabel 3 memperlihatkan hal-hal sebagai berikut.

- Sebelum pembelajaran, hasil uji KruskalWallis pada taraf signifikansi $\alpha=0,05$ menunjukkan bahwa kemampuan berpikir statistis mahasiswa regular dan mengulang yang memperoleh pembelajaran MEAs yang dimodifikasi dengan mahasiswa regular yang memperoleh pembelajaran konvensional tidak berbeda secara signifikan. Jadi sebelum pembelajaran, kemampuan berpikir statistis mahasiswa regular maupun mahasiswa mengulang tidak berbeda secara signifikan.

- Setelah pembelajaran, hasil uji One Way ANOVA pada taraf signifikansi $\alpha=0,05$ menunjukkan bahwa ada perbedaan kemampuan berpikir statistis (KBS_Akhir) yang signifikan antara mahasiswa regular dan mengulang yang memperoleh pembelajaran MEAs yang dimodifikasi dengan mahasiswa regular yang memperoleh pembelajaran konvensional. Selanjutnya dari hasil uji lanjutan (Posthoc Test) dengan menggunakan uji Schaffe pada taraf signifikansi $\alpha=0,05$ menunjukkan bahwa:

- setelah pembelajaran, kemampuan berpikir statistis mahasiswa regular $\left(\mathrm{E}_{1}\right)$ yang memperoleh pembelajaran MEAs yang dimodifikasi lebih tinggi secara signifi- kan daripada mahasiswa regular $(\mathrm{K})$ yang memperoleh pembelajaran konvensional;

- setelah pembelajaran, kemampuan berpikir statistis mahasiswa mengulang $\left(\mathrm{E}_{2}\right)$ yang memperoleh pembelajaran MEAs yang dimodifikasi lebih tinggi secara signifikan daripada mahasiswa regular $(\mathrm{K})$ yang memperoleh pembelajaran konvensional; dan

- setelah pembelajaran, tidak ada perbedaan kemampuan berpikir statistis yang signifikan antara mahasiswa regular $\left(\mathrm{E}_{1}\right)$ dengan mahasiswa mengulang $\left(\mathrm{E}_{2}\right)$ yang memperoleh pembelajaran MEAs yang dimodifikasi.

- Hasil uji One Way ANOVA pada taraf signifikansi $\alpha=0,05$ menunjukkan bahwa ada perbedaan peningkatan kemampuan berpikir statistis (Gain_KBS) yang signifikan antara mahasiswa regular dan mengulang yang memperoleh pembelajaran MEAs yang dimodifikasi dengan mahasiswa regular yang memperoleh pembelajaran konvensional. Selanjutnya dari hasil uji lanjutan (Posthoc Test) dengan menggunakan uji Schaffe pada taraf signifikansi $\alpha=0,05$ diketahui seperti berikut.

- Peningkatan kemampuan berpikir statistis mahasiswa regular $\left(\mathrm{E}_{1}\right)$ yang memperoleh pembelajaran MEAs yang dimodifikasi lebih tinggi secara signifikan daripada mahasiswa regular (K) yang memperoleh pembelajaran konvensional.

- Peningkatan kemampuan berpikir statistis akhir mahasiswa mengulang $\left(\mathrm{E}_{2}\right)$ yang memperoleh pembelajaran MEAs yang dimodifikasi lebih tinggi secara signifikan daripada mahasiswa regular $(\mathrm{K})$ yang memperoleh pembelajaran konvensional.

- Tidak ada perbedaan peningkatan kemampuan berpikir statistis akhir yang signifikan antara mahasiswa regular $\left(\mathrm{E}_{1}\right)$ dengan mahasiswa mengulang $\left(\mathrm{E}_{2}\right)$ yang memperoleh pembelajaran MEAs yang dimodifikasi.

Berdasarkan hasil analisis statistik deskriptif dan inferensial di atas dapat disimpul- 
kan bahwa sebelum memperoleh pembelajaran, kemampuan berpikir statistis mahasiswa regular dan mengulang tidak berbeda secara signifikan. Setelah pembelajaran, kemampuan berpikir statistis mahasiswa regular maupun mengulang yang memperoleh pembelajaran MEAs yang dimodifikasi lebih tinggi secara signifikan daripada mahasiswa yang meperoleh pembelajaran konvensional. Peningkatan kemampuan berpikir statistis mahasiswa regular maupun mengulang yang memperoleh pembelajaran MEAs yang dimodifikasi lebih tinggi secara signifikan daripada mahasiswa yang meperoleh pembelajaran konvensional.

Ini menunjukkan bahwa pembelajaran MEAs yang dimodifikasi secara signifikan lebih dapat mengoptimalkan peningkatan kemampuan berpikir statistis mahasiswa daripada pembelajaran konvensional. Secara teoritis hal ini terjadi oleh karena kualitas bahan ajar pembelajaran MEAs yang dimodifikasi lebih baik daripada pembelajaran konvensional (Suryadi, 2010). Alasan teoritis lainnya adalah pembelajaran MEAs didasarkan pada filosofi kontruktivisme bahwa siswa harus aktif secara mental membangun struktur pengetahuannya berdasarkan kematangan kognitif yang dimilikinya. Selanjutnya keenam prinsip yang ada pada pembelajaran MEAs sesuai dengan teori perkembangan kognitif dari Piaget bahwa belajar merupakan proses asimilasi dan akomodasi. Proses asimilasi pada pembelajaran MEAs terjadi pada prinsip konstruksi dan realitas, sedangkan proses akomodasi pada pembelajaran MEAs terjadi pada prinsip self-assessment; prinsip dokumentasi; prinsip reusability dan berbagi-kemampuan; dan prinsip prototipe yang efektif.

Selain filosofi kontruktivisme dan teori perkembangan kognitif Piaget, teori Vygotsky juga dapat dijadikan dasar dari kerangka kerja teoritis dari pembelajaran MEAs, pada saat dosen memberi arahan, dorongan, dan membantu mahsiswa pada awal pembelajaran ketika dosen memperkenalkan konteks permasalahan. Untuk proses pembelajaran MEAs selanjutnya lebih ditekankan kepada keaktifan mahasiswa. Sehingga pembelajaran tidak berpusat pada dosen akan tetapi mahasiswa yang aktif belajar, menggali pengetahuannya secara mandiri. Hal ini sangat tepat untuk pendekatan pembelajaran yang digunakan di perguruan tinggi yaitu andragogi. (Nurhayati, 2011).

\section{Pengaruh Interaksi Faktor Pembelajaran dan Faktor Kemampuan Statistis Awal ter- hadap Peningkatan Kemampuan Berpikir Statistis Mahasiswa}

Hasil uji ANOVA dua jalur (Two Way ANOVA) untuk pengaruh interaksi antara faktor pembelajaran dengan kemampuan statistis awal terhadap peningkatan kemampuan berpikir statistis mahasiswa disajikan dalam Diagram 1 dan Tabel 4.

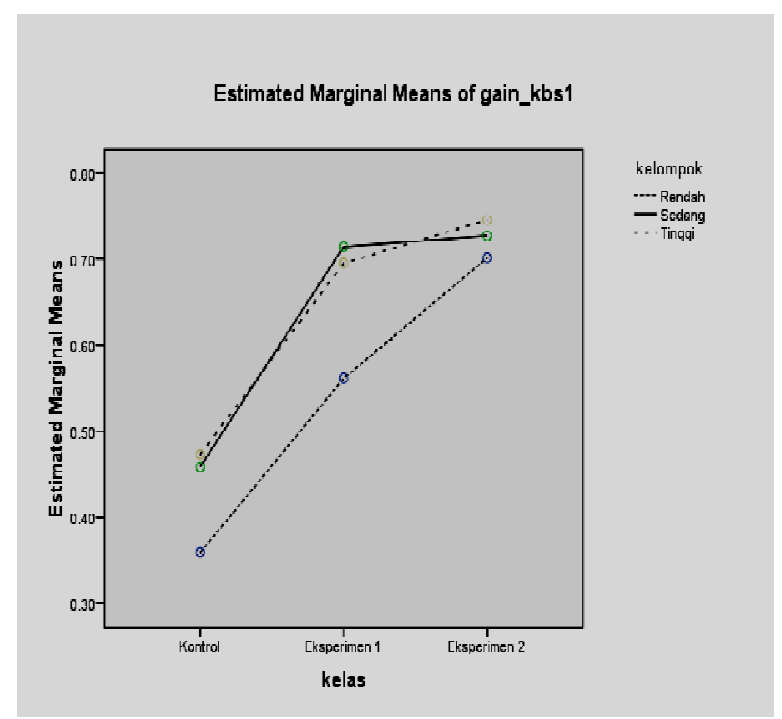

\section{Diagram 1: Interaksi antara Faktor Pembe- lajaran dengan Kemampuan Statistis Awal terhadap Peningkatan Kemampuan Berpikir Statistis Mahasiswa}

Dari Diagram 1 terlihat bahwa ada interaksi antara faktor pembelajaran (MEAs yang dimodifikasi dan konvensional) yang digunakan dan kemampuan statistis awal mahasiswa (tinggi, sedang, rendah), akan tetapi interaksinya tidak berpengaruh signifikan terhadap peningkatan kemampuan berpikir statistis mahasiswa, karena pengaruhnya hanya sebesar $1,5 \%$. 


\section{PENUTUP}

Berdasarkan hasil penelitian dapat disimpulkan hal-hal sebagai berikut.

(1)Pembelajaran MEAs yang telah dikembangkan oleh Lesh \& Doerr (2003) Diefes-Dux, Imbrie \& Moore (2005), Moore (2006), dan Diefes-Dux \& Imbrie (2007), Garfield, delMas dan Zieffler (2010) telah dimodifikasi oleh peneliti dengan menggunakan DDR melalui tiga tahap, yaitu: (1) Analisis situasi didaktis yang dilakukan dosen sebelum uji coba bahan ajar; (2) Analisis metapedadidaktik yang dilakukan dosen pada saat uji coba bahan ajar; dan (3) Analisis retrosfektif yang dilakukan setelah uji coba bahan ajar. Pembelajaran MEAs yang dimodifikasi masih mempertahankan enam prinsip dari pembelajaran MEAs, yaitu: prinsip konstruksi, prinsip realitas, prinsip self-assessment, prinsip dokumentasi, prinsip reusability, dan prinsip prototipe yang efektif. Pada awal pembelajaran MEAs yang dimodifikasi dosen mengajukan serangkaian pertanyaan untuk mengetahui sampai sejauh mana mahasiswa telah menguasai konsep-konsep dasar dari materi yang akan diajarkan. Pada akhir pembelajaran MEAs yang dimodifikasi, dosen menugaskan mahasiswa untuk mempelajari sendiri dan membuat peta konsep materi yang akan diajarkan pada pertemuan selanjutnya.

(2)Peningkatan kemampuan berpikir statistis mahasiswa yang memperoleh pembelajaran MEAs yang dimodifikasi lebih tinggi secara signifikan daripada mahasiswa yang memperoleh pembelajaran konvensional.

(3)Tidak ada perbedaan peningkatan kemampuan berpikir statistis antara mahasiswa kelompok tinggi, sedang, dan bawah.

(4)Tidak ada pengaruh interaksi antara kemampuan statistis awal dengan peningkatan kemampuan berpikir statistis mahasiswa yang memperoleh pembelajaran MEAs yang dimodifikasi.

\section{UCAPAN TERIMA KASIH}

Pada bagian ini izinkan saya untuk mengucapkan terima kasih dan penghargaan yang setinggi-tingginya kepada: Prof. Dr. H. Didi Suryadi (SPs UPI) sebagai promotor; Prof. Jozua Sabandar, M.A. Ph.D (SPs UPI) sebagai copromotor; Prof. Dr. Sutawanir Darwis (ITB) sebagai anggota promotor; Prof. H. Yaya S Kusumah, M.Sc., Ph.D (UPI) sebagai Kaprodi S3 Pendidikan Matematika SPs UPI; dan Prof. Dr. M. Salman, A.N (ITB) sebagai penguji luar Perguruan Tinggi yang telah banyak membantu, mengarahkan, membimbing, dan menyempurnakan tulisan ini.

\section{DAFTAR PUSTAKA}

Ben-Zvi \& Friedlander. 2010. Statistical a Technological Environment. Rehovot, Israel: The Weizmann Institute of Science.

Chance, B. L. 2002. "Components of Statistical Thinking and Implications for Instruction and Assessment". Journal of Statistics Education, 10(3). Online: www.amstat.org/publications /jse/ v10n3/chance.html.

delMas, Robert C. 2002. "Statistical Literacy, Reasoning, and Learning: A Commentary". Journal of Statistics Education, Volume 10, Number 3 (2002) http://www.amstat. org /publications/ jse/v10n3/ delmas_discussion.html.

Diefes-Dux, H. A., Imbrie, P. K., \& Moore, T. J. 2005. "First-Year Engineering Themed Seminar - A Mechanism for Conveying the Interdisciplinary Nature of Engineering". Paper Presented at the 2005 American Society for Engineering Education National Conference, Portland, OR.

Diefes-Dux, H. A., Moore, T. J., \& Imbrie, P. K. 2007. "How team Effectiveness Impacts the Quality of Solutions to OpenEnded Problems". Distributed journal Proceedings from the International Conference on Research in Engineering Education, Published in the October 2007 Special Issue of the Journal of Engineering Education, 96(4). 
Garfield, delMas \& Zieffler. 2010. "Developing Tertiary-Level Students' Statistical Thinking Through the Use of ModelEleciting Activities". ICOTS8 (2010) Invited Paper.

Gaspersz, V. 2006. Teknik Analisis Dalam Penelitian Percobaan. Bandung: Tarsito.

Jones, Thornton, Langrall \& Mooney. 2000. “A Framework for Characterizing Children's Statistical Thinking". Mathematical Thinking and Learning, 2(4), 269-307 Copyright () 2000, Lawrence Erlbaum Associates, Inc.

Lesh, R., \& Doerr, H. M. 2003. "Beyond Constructivism: Models and Modeling Perspectives on Mathematics Teaching, Learning, and Problem Solving”. In R. Lesh \& H. M. Doerr (Eds.). Beyond Constructivism: Models and Modeling Perspectives on Mathematics Problem Solving, Learning, and Teaching (pp. 3-33). Mahwah, NJ: Lawrence Erlbaum.
Martadiputra, B.A.P. dan Tapilouw. 2011. Kajian tentang Kemampuan Berpikir Statistis Mahasiswa S1 Jurusan Pendidikann Matematika FPMIPA UPI.

Nurhayati, E. 2011. Pskologi Pendidikan Inovatif. Yogyakarta: Pustaka Pelajar.

Suryadi, D. 2010. "Didactical Design Researh (DDR) dalam Pengembangan Pembelajaran Matematika I". Bandung: Seminar Nasional Pembelajaran MIPA di UM Malang, 13 November 2010.

Zawojewski, J., Bowman, K., \& Diefes-Dux, H. A. 2008. Mathematical Modeling in Engineering Education: Designing Experiences for All Students. Rotterdam, the Netherlands: Sense Publishers. 